\title{
Use of drone (UAV) as a tool for work safety inspection for roofing activities in civil construction: a systematic review
}

\author{
G. C. G. Macêdo ${ }^{1}$, T. Zlatar², B. Barkokébas Jr³
}

\begin{abstract}
${ }^{1}$ Laboratory on Occupational Safety and Hygiene (LSHT), Polytechnic School (POLI) of the University of Pernambuco (UPE), Recife, BR, (gercica.macedo@gmail.com) ORCID 0000-0001-6620-9091, 2Laboratory on Occupational Safety and Hygiene (LSHT), Polytechnic School (POLI) of the University of Pernambuco (UPE), Recife, BR, (tomi.zlatar@gmail.com) ORCID 0000-0002-8915-908X, ${ }^{3}$ Laboratory on Occupational Safety and Hygiene (LSHT), Polytechnic School (POLI) of the University of Pernambuco (UPE), Recife, BR, (beda.jr@upe.br) ORCID 0000-0003-3130-3277.

https://doi.org/10.24840/978-972-752-279-8 0001-0008
\end{abstract}

\begin{abstract}
Introduction: Falls from heights represent one of the most frequent accidents in civil constructions, mainly caused by different roofing activities. The risks should be first evaluated by conducting safety inspections, and then implementing adequate control measures to eliminate or reduce the risks of accidents. New technologies facilitate those inspections and make the processes much more efficient. The objective of this study was to make a systematic review to analyse works which used a drone as a visual tool for such safety inspection activities, systematize main information needed to consider in developing future drone research in civil construction. Methodology: The research was carried out on the Brazilian platform for scientific journals and conferences called "CAPES Portal" through the Preferred Report for Systematic Reviews and Meta-analyzes (PRISMA) methodology. Several keywords were used for searching, including: "Construction", "Construction Safety", "Safety Inspection", "Safety Management", "Drone", "Unmanned Aerial Vehicles". Results and Discussion: In total, 102 articles were identified through the searching. After applying all the inclusion and exclusion criteria (published in the last 10 years, published in English or Portuguese language), In addition, the articles were included only if related to the use of drones in civil construction and if had some relationship with work safety inspection. A total number of 15 articles fulfilled the selection criteria's and were included in this review. The information about the analysed studies included information such as author/reference, the objective of the study, the country where the study was conducted, the activities which were analysed, conclusions, limitations and the type of the drone which was used in the research. In total, 8 of the 15 studies were developed in the United States, representing $53 \%$ of the total, while other studies are from Germany (4), Brazil (2), Australia (1) and Spain (1). Most studies analysed the inspection of bridges and roofs. Conclusions: Studies have shown that there is evidence of the advantages of using drones to assist in safety inspections in civil construction, especially in bridges and roofs.
\end{abstract}

Keywords: Civil construction, Drone, UAV, Safety inspection, Work safety.

\section{INTRODUCTION}

According to the Brazilian Ministry of Social Security (2014), the civil construction sector has a high economic importance, whose relevance is also manifested in the large number of workers who work in this sector, which is traditionally labour-intensive. However, the unplanned growth of this activity has caused a lot of damage to those involved (ZLATAR \& BARKOKEBAS JR, 2018).

Roofing activities are one of the most dangerous tasks in construction. Workers who perform activities on the roof are three times more likely to suffer fatal occupational injuries when compared to other construction workers (DONG et al., 2013). Falls are the main cause of fatalities in roofing activities, representing 76\% of fatalities between 2003 and 2009 (BLS, 2012).

For roofing activities before any work is started, a risk assessment must be carried out. They should be collective protection measures against fall risks based on the results of risk assessments, before selecting individual protection measures. In addition, it is necessary to ensure safe access, places and workplaces, since tiles may not constitute a safe base (BARBOSA FILHO, 2018). 
Safety inspections are very effective in preventing accidents. Abudayyeh et al. (2006) affirm that the incidence rates of accidents and illnesses are significantly lower in the companies that carried out safety inspections.

Therefore, new technologies are essential to facilitate inspection activities and make processes more efficient (SAURIN et al., 2005). According to Irizarry \& Kim (2015), the use of the Unmanned Aerial Vehicle (UAV), or drone, can contribute to the process of monitoring safety, detecting and correcting errors, corroborating the reduction of accidents. The use of UAVs to perform safety inspection is promising, since it eliminates the need for lifting equipment and specialized operators, in addition to ensuring increased safety during the inspection process and carrying out the activity more efficiently and economically (ESCHMANN et al., 2012; MORGENTHAL; HALLERMANN, 2014).

The objective of this study was to identify and analyse the works that used drones as a visual tool for safety inspection activities, in addition to systematizing the main information needed to be considered in the development of future research with drones in civil construction.

\section{MATERIALS AND METHODS}

The methodology used for the research followed the guidelines of the items of the Preferred Report for Systematic Reviews and Meta-analyzes (PRISMA) (Liberati et al., 2009). The research was carried out on the Brazilian database of scientific articles "Journals Portal of the Coordination for the Improvement of Higher Education Personnel - CAPES" (Coordination for the Improvement of Higher Education Personnel, 2017).

Several keywords in the English language were chosen for searching purposes: "Construction", "Construction Safety", "Safety Inspection", "Safety Management", "Drone", "Unmanned Aerial Vehicles", using the "OR" combination present at the CAPES website. The articles were searched through sections "in the title" and "in the subject". Works older than ten years and published in a language other than English and Portuguese were excluded. Articles were included if related to the use of drones in civil construction and if they had some relationship with work safety inspection.

\section{RESULTS AND DISCUSSION}

In total, the search resulted in founding 102 articles. After applying defined filters, excluding repeated articles, articles published in a language other than English and Portuguese, including only articles published in the period from 2009 to 2019, and through the selection of articles by the title that were related to the topic of interest, the number of possible articles was reduced to 42 articles for further consideration.

The next step was a selection by summary, excluding works that did not deal exclusively with drones in civil construction, which reduced the number to 32 articles. The articles were read and analysed, and finally including only 15 of them which dealt with using drones as a tool for safety inspection in civil construction. Figure 1 shows the selection process of articles used in the present systematic review. 

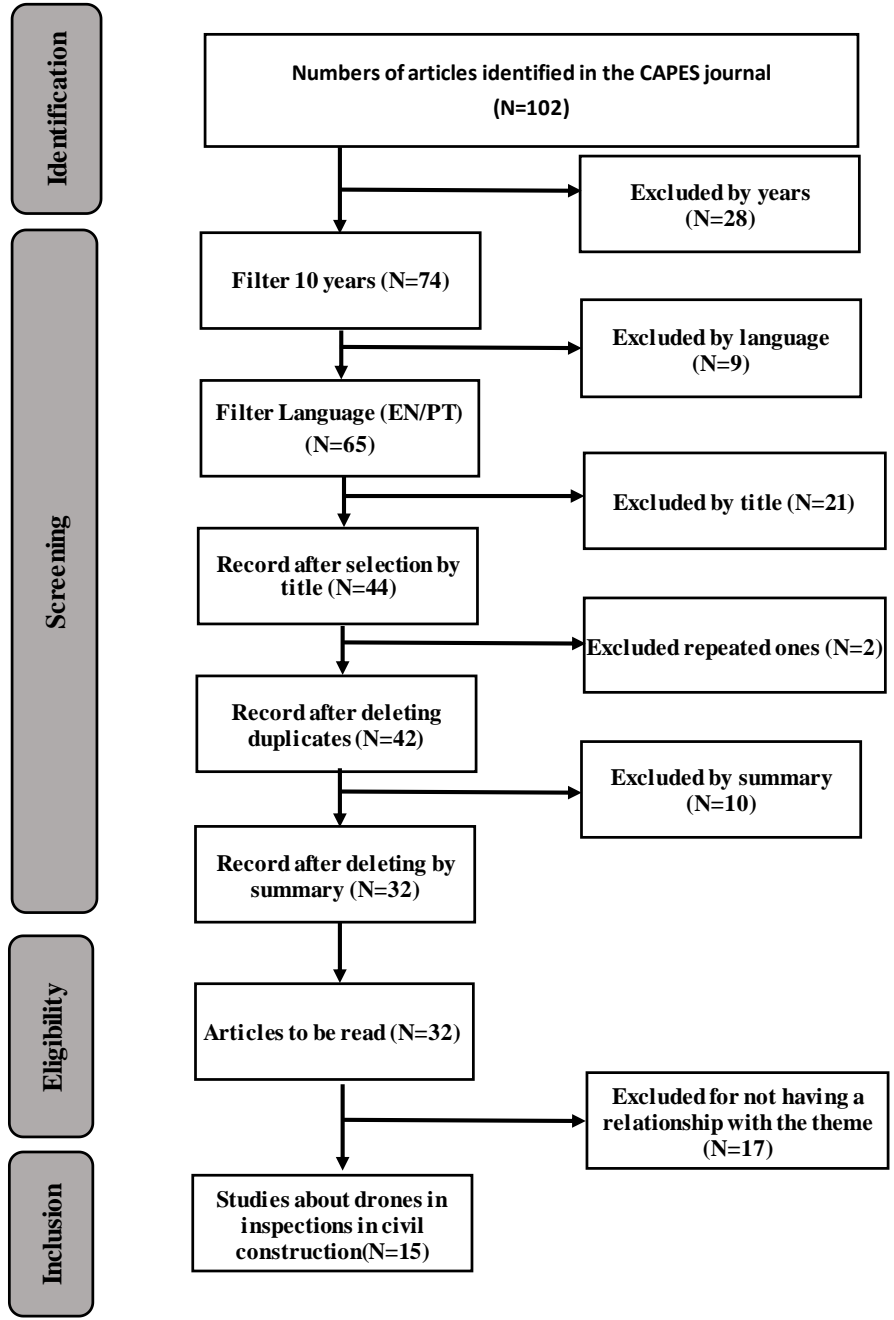

Figure 1. Flowchart of the carried out research

Table 1 illustrates the included articles and some resumed data such as the objective, country of study, analysed activities, conclusions, limitations and the type of drone used in the research.

The analysed studies show that there is a broad range of applications and perspectives of using a drone as a visual tool for safety inspection activities in civil construction. Regarding the countries of origin of the studies, 8 of the 15 studies were developed in the United States, representing $53 \%$ of the total, while other studies are from Germany (4), Brazil (2), Australia (1) and Spain (1). Most studies analysed the inspection of bridges and roofs. The studies highlighted the importance of having more in-depth studies on the subject, the high risk of workers involved in traditional inspections due to difficulties to the access on bridges and roofs.

The most analysed criteria for choosing the ideal drone are: flight time, type of camera, camera resolution, payload capacity, cost, ability to transmit video in real-time, autonomous navigation, remote control distance, light in the drone. Most of the included studies used a drone in the line of DJI Phantom 2, 3 or 4. This is due to accessible cost in relation to the competitors and the efficiency of the inspection in civil construction. Noted limitations for conducting studies were: not enough regulation, low light conditions, limited camera rotation, need for training, flight stabilization, flight time, battery life, weather conditions, sensor, the privacy of workers, obstacles. 


\section{DeE}

Table 1. Information about the analysed studies

\begin{tabular}{|c|c|c|c|c|c|c|c|}
\hline № & Author/References & Objective & Country & Activities analyzed & Conclusions & Limitations & Used drone \\
\hline 1 & (Duque et al., 2018) & $\begin{array}{l}\text { summarize conclusions about } \\
\text { current drone techniques to } \\
\text { inspect and analyse different } \\
\text { infrastructures }\end{array}$ & USA & & $\begin{array}{l}\text { Drone versatility to detect damage to } \\
\text { different structures and materials }\end{array}$ & $\begin{array}{l}\text { regulations, low light } \\
\text { conditions, GPS, camera } \\
\text { rotation, traffic safety }\end{array}$ & $\begin{array}{l}\text { senseFly albris; } \\
\text { DJI Phantom } 4\end{array}$ \\
\hline 2 & (Blinn \& Issa,2016) & $\begin{array}{c}\text { compare the use of a drone to } \\
\text { the current state and use of } \\
\text { aerial images }\end{array}$ & USA & $\begin{array}{l}\text { power line inspection; } \\
\text { construction and } \\
\text { maintenance }\end{array}$ & $\begin{array}{l}95 \% \text { confidence that the use of a drone is } \\
\text { less expensive and more financially viable }\end{array}$ & regulations, formal training & DJI Phantom 2 \\
\hline 3 & $\begin{array}{l}\text { (Eschmann et } \\
\text { al.,2012) }\end{array}$ & $\begin{array}{c}\text { scan buildings for } \\
\text { inspection and monitoring } \\
\text { with a high-resolution digital } \\
\text { camera }\end{array}$ & Germany & facade inspection & $\begin{array}{l}\text { represents an adequate } \\
\text { technique to create a database }\end{array}$ & $\begin{array}{l}\text { flight stabilization } \\
\text { platform, anti-collision }\end{array}$ & $\begin{array}{l}\text { Octocopter MAV } \\
\text { inspection platform }\end{array}$ \\
\hline 4 & $\begin{array}{c}\text { (Gheisari \& } \\
\text { Esmaeilli,2016) }\end{array}$ & $\begin{array}{l}\text { identify security practices that } \\
\text { can be improved using drone } \\
\text { and distinguish users' needs } \\
\text { and techniques }\end{array}$ & USA & $\begin{array}{l}\text { proximity to vehicles; } \\
\text { cranes, near an } \\
\text { unprotected ledge; } \\
\text { opening; blind spot of } \\
\text { heavy equipment }\end{array}$ & $\begin{array}{c}\text { Use of the important drone in the vicinity of } \\
\text { vehicles / cranes / } \\
\text { near an unprotected edge / unprotected } \\
\text { opening / in the blind spot of heavy } \\
\text { equipment }\end{array}$ & flight time & \\
\hline 5 & $\begin{array}{l}\text { (Gillins; Gillins; } \\
\text { Parrish,2016) }\end{array}$ & $\begin{array}{l}\text { investigate whether the } \\
\text { images obtained are } \\
\text { comparable to the images that } \\
\text { would be acquired } \\
\text { with a camera during a } \\
\text { conventional inspection }\end{array}$ & Germany & bridge inspection & lack of zoom on the camera & & \\
\hline 6 & (Herrmann,2016) & $\begin{array}{l}\text { examine current and } \\
\text { proposed regulations } \\
\text { governing the use of drones } \\
\text { and their applicability to the } \\
\text { construction industry }\end{array}$ & USA & & & $\begin{array}{l}\text { uncertainty about whether } \\
\text { time and money invested in } \\
\text { getting approved } \\
\text { for drone use under current } \\
\text { rules will be beneficial }\end{array}$ & DJI Phantom 3 \\
\hline 7 & $\begin{array}{l}\text { (Irizarry; Costa; Kim, } \\
\text { 2015a) }\end{array}$ & $\begin{array}{l}\text { identify potentials } \\
\text { visual asset applications } \\
\text { obtained from the drone for } \\
\text { management tasks } \\
\text { construction }\end{array}$ & $\begin{array}{l}\text { USA and } \\
\text { Brazil }\end{array}$ & all & $\begin{array}{l}\text { monitoring the progress of the } \\
\text { the project, assessment of the workplace, } \\
\text { logistics, monitoring of safety conditions and } \\
\text { quality work inspections carried out }\end{array}$ & $\begin{array}{l}\text { flight time, photo memory } \\
\text { capacity, viewing angles }\end{array}$ & DJI Phantom 2 \\
\hline 8 & $\begin{array}{c}\text { (Irizarry \& } \\
\text { Gheisari,2016) }\end{array}$ & $\begin{array}{l}\text { security inspection and how a } \\
\text { drone can play the role of a } \\
\text { security inspection assistant }\end{array}$ & USA & $\begin{array}{l}\text { high parts of walls and } \\
\text { roofs }\end{array}$ & $\begin{array}{l}\text { explore potential benefits for security } \\
\text { managers and check the current security } \\
\text { situation of workers, materials and } \\
\text { equipment }\end{array}$ & $\begin{array}{l}\text { improve battery life; weather } \\
\text { conditions, endangering the } \\
\text { safety of workers in the } \\
\text { workplace }\end{array}$ & $\begin{array}{l}\text { AR.Drone } \\
\text { Quadricopter }\end{array}$ \\
\hline
\end{tabular}




\begin{tabular}{|c|c|c|c|c|c|c|c|}
\hline 9 & (Roca et al.,2013) & $\begin{array}{l}\text { area inspection } \\
\text { unreachable (high walls and } \\
\text { roofs) for data acquisition }\end{array}$ & Spain & & $\begin{array}{l}\text { more competitive for the acquisition of data } \\
\text { from hard-to-reach places, such as roofs and } \\
\text { high facades of buildings }\end{array}$ & $\begin{array}{l}\text { sensor, material and lighting } \\
\text { conditions }\end{array}$ & $\begin{array}{c}\text { Okto XL/ } \\
\text { Mikrokopter Okto XL }\end{array}$ \\
\hline 10 & $\begin{array}{c}\text { (Kim; Irizarry; Costa } \\
\text {,2016) }\end{array}$ & $\begin{array}{l}\text { identify needs, operational } \\
\text { challenges, potential factors } \\
\text { that influence the drone } \\
\text { performance, and potential } \\
\text { performance measures }\end{array}$ & USA & $\begin{array}{l}\text { roof, assembly and } \\
\text { disassembly, cleaning } \\
\text { services, facade } \\
\text { processes }\end{array}$ & $\begin{array}{l}\text { "Ease of user interface for drone operation" } \\
\text { and "Quality of visual assets" were identified } \\
\text { as the most important factors influencing } \\
\text { performance }\end{array}$ & $\begin{array}{l}\text { limitation of battery life, } \\
\text { weather conditions, worker } \\
\text { privacy, obstacles }\end{array}$ & \\
\hline 11 & $\begin{array}{l}\text { (Rodrigues et } \\
\text { al.,2017) }\end{array}$ & $\begin{array}{l}\text { evaluate the applicability of } \\
\text { the drone for a safety } \\
\text { inspection at worksites } \\
\text { construction, with a focus on } \\
\text { identifying } \\
\text { unconformities }\end{array}$ & Brazil & & $\begin{array}{l}\text { development and validation of a process for } \\
\text { a security inspection with UAV }\end{array}$ & $\begin{array}{l}\text { physical barriers; weather } \\
\text { conditions; regulations; } \\
\text { formation; } \\
\text { poor view of internal areas; } \\
\text { need to improve real-time } \\
\text { feedback; poorly structured } \\
\text { safety management system at } \\
\text { the construction site }\end{array}$ & DJI Phantom 3 \\
\hline 12 & $\begin{array}{l}\text { (Seo; Duque; } \\
\text { Wacker, 2018) }\end{array}$ & $\begin{array}{l}\text { evaluate the capabilities of } \\
\text { robot technology as an } \\
\text { inspection tool; support } \\
\text { inspections of conventional } \\
\text { bridges }\end{array}$ & USA & bridge inspection & $\begin{array}{l}\text { The use of photogrammetry software } \\
\text { allowed a more comprehensive and detailed } \\
\text { view of the damage; the drone was able to } \\
\text { identify cracking, chipping, corrosion, } \\
\text { moisture on the bridge }\end{array}$ & $\begin{array}{l}\text { unfavorable weather } \\
\text { conditions }\end{array}$ & DJI Phantom 4 \\
\hline 13 & $\begin{array}{l}\text { Freimuth \& Konig } \\
\qquad(2018)\end{array}$ & $\begin{array}{l}\text { plan inspections in a 3D } \\
\text { environment; the combination } \\
\text { of BIM and open source } \\
\text { autopilot technology is the } \\
\text { basis for a } \\
\text { systematic approach }\end{array}$ & Germany & analysis of facades, roofs & $\begin{array}{l}\text { visual and factual information about flight } \\
\text { conditions in the planning phase; capture } \\
\text { rich information, generating various points } \\
\text { of view for each point of interest, } \\
\text { accompanied with virtual previews in the } \\
\text { planning application }\end{array}$ & & $\begin{array}{l}\text { octo } \\
\text { copter }\end{array}$ \\
\hline 14 & Chan et al. (2015) & $\begin{array}{l}\text { provide a context for using } \\
\text { drones for visual bridge } \\
\text { inspections, and identify } \\
\text { obstacles }\end{array}$ & Australia & bridge inspection & $\begin{array}{l}\text { technology has the potential to significantly } \\
\text { reduce the costs of } \\
\text { general inspection and inconvenience to } \\
\text { passengers }\end{array}$ & $\begin{array}{l}\text { training, certification; } \\
\text { proximity to structures and the } \\
\text { public; stability }\end{array}$ & $\begin{array}{l}\text { Eight-armed UAV } \\
\text { (developed at the } \\
\text { University) }\end{array}$ \\
\hline 15 & $\begin{array}{c}\text { Hallermann \& } \\
\text { Morgenthal (2014) }\end{array}$ & $\begin{array}{l}\text { new visual inspection method } \\
\text { based on aerial photos and } \\
\text { video taken by a drone }\end{array}$ & Germany & bridge inspection & $\begin{array}{l}\text { generates much lower costs compared to the } \\
\text { units of } \\
\text { conventional control systems, reduced risk } \\
\text { of operation during inspections }\end{array}$ & $\begin{array}{l}\text { instability due to the wind; } \\
\text { small batteries; climate } \\
\text { changes }\end{array}$ & $\begin{array}{l}\text { Flight system BUW } \\
\text { Falcon Photo }\end{array}$ \\
\hline
\end{tabular}


Despite some limitations, the included studies identified numerous benefit, based on the criteria considered in the studies included. Some of them are: drone versatility to detect damage in different structures and materials; financially viable; monitoring the progress of the project, assessing the logistics workplace, monitoring safety conditions and carrying out quality work inspections; checks the current safety situation of workers, materials and equipment, by having direct interaction with workers; more competitive for the acquisition of data from hard to reach places, such as roofs and high parts of building facades; significantly reduce the costs of general inspection; generates much lower costs; reducing the risk of the activity.

According to Rodrigues et al. (2017), some benefits are listed with respect to the applicability of drones in labour safety inspections in civil construction: reduction of variability; increasing the transparency of unsafe conditions; detailed information about unsafe and safe conditions; registration of security non-conformity requirements and good practices, allowing the analysis of different perspectives; use of indicators and information for decision making; use of visual assets and inspection results for training in occupational safety; cost-effectiveness of viability; potential improvement in safety-related worker behaviour.

Gheisari \& Esmaeilli (2016) also mention that drones can provide several advantages for occupational safety managers: drones can move faster than humans; it can reach inaccessible areas of workplaces; it can be equipped with video cameras, wireless sensors, radar or communication hardware for real-time data transfer.

The authors Irizarry, Coast, Kim (2015a) emphasize that drone can provide a low-cost solution for exploring aerial photography-based construction inspection techniques, such as in roofing and building facade activities, and for other applications that would otherwise be impractical or insecure.

Regarding the results obtained in the included studies, according to Irizarry, Coast, Kim (2015a), with the application of the drone, it was possible to improve management in civil construction. According to Rodrigues et al. (2017) it is possible to improve safety inspection in workplaces through better visualization of working conditions. In the results obtained by Seo, Duke, Wacker (2018), the drone is a great potential to complement inspection methods. In the study by Freimuth \& Konig (2018) it is mentioned that UAV makes inspection automated and that it captures significant data with only little necessary inputs and is operational. According to Chan et al. (2015) the quality of the drone-based inspection may be better than the human-operated method.

\section{CONCLUSIONS}

Studies have shown that there is evidence of the advantages of using drones to assist in safety inspections in civil construction, especially in bridges and roofs. It generates data and images in a very efficient way and can assist in different phases of the construction process: before, during and after the execution of bridge/roof works. Drones provide the safety inspection to be conducted with higher safety, speed and lower costs, requiring fewer resources compared to the traditional method.

Several benefits and limitations were presented, which should serve as a support in the development of future researches using drones in civil construction. The characteristics of drones should be chosen based on the objective and particularities of the research and environmental conditions in which the drone will be used. 
Therefore, some of this information that must be considered are: the most relevant activities to be analyzed; criteria that must be considered when choosing the ideal drone related to the particularities of each situation; difficulties, limitations and benefits with the use of the drone for labour safety inspections in civil construction, among other possibilities.

\section{References}

ABUDAYYEH, O., FREDERICKS, T.K., BUTT, S.E., SHAAR, A. 2006. "An investigation of management's commitment to construction safety". International Journal of Project Management, v. 24, n.2, p. 167-174.

BARBOSA FILHO, A. N. 2018. "Occupational safety and environmental management". São Paulo: Atlas. ISBN: 9788597018318. 5 ed. 2018.

BLINN, N., ISSA, R.R.A. 2016. "Feasibility Assessment of Unmanned Aircraft Systems for Construction Management Applications". In: Construction Research Congress, San Juan, p. 2593-2603. Proceedings.

CHAN, B. et al. 2015. "Towards UAV-based bridge inspection systems : a review and an application perspective". Structural Monitoring and Maintenance. Vol. 2, No. 3. 283-300 $2015 . \quad$ DOI: http://dx.doi.org/10.12989/smm.2015.2.3.283.

DONG, XIUWEN SUE, SANG D. CHOI, ET AL. 2013. "Fatal Falls from Roofs among U.S Construction Workers". Journal of Safety Research, vol. 44, no. 1, National Safety Council and Elsevier Ltd, pp. 17 24, doi:10.1016/j.jsr.2012.08.024.

DUQUE, L. et al. 2018. "Synthesis of Unmanned Aerial Vehicle Applications for Infrastructures". v. 32, n. 4, p. 1-10, J. Perform. Constr. Facil., 32(4): 04018046.

ESCHMANN, C. et al. 2012. “Unmanned Aircraft Systems for Remote Building Inspection and Monitoring”. p. 1-8, 6th European Workshop on Structural Health Monitoring - Th.2.B.1.

FREIMUTH, H., KÖNIG, M. 2018. "Automation in Construction Planning and executing construction inspections with unmanned aerial vehicles". Automation in Construction, v. 96, n. March 2017, p. 540-553.

GHEISARI, M., ESMAEILI, B. 2016. "Unmanned Aerial Systems (UAS) for construction safety applications". In: Construction Research Congress, San Juan, p. 2642-2650. Proceedings.

GILLINS, M. N., GILLINS, D. T., PARRISH, C. 2016. "Cost-effective bridge safety inspections using Unmanned Aircraft Systems (UAS)". In: Geotechnical and Structural Engineering Congress, Phoenix, p. 131-140. Proceedings.

HALLERMANN, N., MORGENTHAL, G. 2014. "Visual inspection strategies for large bridges using Unmanned Aerial Vehicles (UAV)". n. Conference Paper. July.

HERRMANN, M. 2016. "Unmanned aerial vehicles in construction: an overview of current and proposed rules". In: Construction Research Congress, San Juan, p. 588-596. Proceedings.

IRIZARRY, J., COSTA, D.B., KIM, S. 2015. “Potential applications of Unmanned Aerial systems for construction management tasks". In: International Conference on Innovative Production and Construction (IPC), July, Perth. Proceedings.

IRIZARRY, J., COSTA, D.B., KIM, S. 2015a. "Potential applications of Unmanned Aerial systems for construction management tasks". In: International Conference on Innovative Production and Construction (IPC), July, Perth. Proceedings...

IRIZARRY, J. et al. 2016. "Exploratory Study of Potential Applications of Unmanned Aerial Systems for Construction Management Tasks". v. 2, n. 2015, p. 1-10.

KIM, S., IRIZARY, J., COSTA, D. B. 2016. "Potential Factors Influencing the Performance of Unmanned Aerial System (UAS) Integrated Safety Control for Construction Worksites". Construction Research Congress. American Society of Civil Engineers.

LIBERATI, A., ALTMAN, D.G., TETZLAFF, J. 2009. "The PRISMA statement for reporting systematic reviews and metaanalyses of studies that evaluate healthcare interventions: explanation and elaboration". BMJ; 339: b2700. 
MINISTÉRIO DA PREVIDÊNCIA SOCIAL. 2014. "Informe de Previdência Social". Disponível em: <http://www.previdencia.gov.br/wpcontent/uploads/2014/10/Ret_Offset_Informe_julho_2014.pdf>. Acesso em: 27 maio 2018

MORGENTHAL, G., HALLERMANN, N. 2014. "Quality assessment of Unmanned Aerial Vehicle (UAV) based visual inspection of structures". Advances in Structural Engineering, v. 17, n. 3.

ROCA, D., LAGÜELA, S., Díaz-Vilariño, L., ARIAS, J.A. 2013. “Low-cost aerial unit for outdoor inspection of building façades". Automation in Construction, v. 36, p. 128-135.

RODRIGUES, R. et al. 2017. "Applicability of unmanned aerial system ( UAS ) for safety inspection on construction sites". Safety Science, v. 98, p. 174-185.

SAURIN, T. A. FORMOSO,C.T., CAMBRAIA, F.B., HOWELL, G. 2005. "A cognitive systems engineering perspective of construction safety". In: Annual Conference of the International Group for Lean Construction, 13, 2005, Sydney. Proceedings... Sydney: IGLC.

SEO, J., DUQUE, L., WACKER, J. 2018. "Automation in Construction Drone-enabled bridge inspection methodology and application". Automation in Construction, v. 94, n. October 2017, p. 112-126.

U.S. Bureau of Labor Statistics (BLS). 2012. "Occupational injuries/illnesses and fatalinjury profiles 2003-2009". Fatal occupational injuries by selected worker characteristics and selected industry, all U.S., all ownerships, 2003-2009.

ZLATAR, T; BARKOKÉBAS JR., B. 2018. "Building Information Modelling as a Safety Management Tool for Preventing Falls from Height". 1. ed. Lambert Academic Publishing. 69p. ISBN: 978-613-9-85592-6. 